\title{
Distal Bile Duct Cancer pT1 TNM Finding v7
}

National Cancer Institute

\section{Source}

National Cancer Institute. Distal Bile Duct Cancer PT1 TNM Finding V7. NCI Thesaurus. Code C90249.

Distal bile duct cancer with tumor confined to the bile duct histologically. (from AJCC 7th Ed.) 